Check for updates

Cite this: Chem. Sci., 2018, 9, 5242

Received 9th February 2018

Accepted 3rd May 2018

DOI: $10.1039 / \mathrm{c} 8 \mathrm{sc} 00670 a$

rsc.li/chemical-science

\section{Rationally designed upconversion nanoprobe for simultaneous highly sensitive ratiometric detection of fluoride ions and fluorosis theranostics $\uparrow$}

\begin{abstract}
Yuxin Liu, (D) Anqi Jiang, Qi Jia, Xuejiao Zhai, Lidong Liu, Liyi Ma and Jing Zhou (DD*
For many years, fluorosis has been known as a worldwide disease which seriously diminishes quality of life through skeletal embrittlement and hepatic damage. Aiming to develop novel drugs for simultaneous fluorosis diagnosis and therapy, in this work we explore the feasibility of a novel pyrogallic acidtitanium(IV) complex-modified upconversion nanoprobe (UCNP-PA-Ti) for $\mathrm{F}^{-}$capture and real-time quantification. Utilizing the strong interaction between $\mathrm{Ti}^{4+}$ and $\mathrm{F}^{-}$, the modified $\mathrm{PA}-\mathrm{Ti}$ decomposes in $\mathrm{F}^{-}$-containing solution, which not only weakens the FRET but results in upconversion luminescence $(\mathrm{UCL})$ recovery. Both in vitro and in vivo experiments demonstrate a highly sensitive $\mathrm{F}^{-} \mathrm{UCL}$ response and therapeutic efficiency, which was promising for successful UCL image monitoring and the therapeutic process. Long blood circulation time and low toxicity ensured their safe application for fluorosis theranostics. Our work provides a new possibility for $\mathrm{F}^{-}$concentration detection within fluorosis therapeutic periods and encourages the development of novel drugs for fluorosis theranostics.
\end{abstract}

\section{Introduction}

Fluorine, possessing an important role in keeping bones strong, is an essential macroelement in living systems. ${ }^{1}$ It is mostly present in its ionic state $\left(\mathrm{F}^{-}\right)$, which can be accumulated via both exposure and intake. However, the over-accumulation of $\mathrm{F}^{-}$causes fluorosis, which has symptoms like skeletal embrittlement and hepatic damage, including endocrine disorder, abnormal calcium accumulation, and teeth staining. ${ }^{2,3}$ It is noteworthy that $\mathrm{F}^{-}$can be cleared from blood within a short period by combination with albumin, a typical type of protein in serum, making $\mathrm{F}^{-}$difficult to capture and metabolise. ${ }^{4}$ Therefore, for the development of novel drugs towards fluorosis therapy, drugs should have a strong interaction with $\mathrm{F}^{-}$to capture it from albumins. Typically, the clearance of $\mathrm{F}^{-}$from blood is achieved by the use of calcium and magnesium salts, producing insoluble depositions such as $\mathrm{CaF}_{2}$ and $\mathrm{MgF}_{2}{ }^{5} \mathrm{~A}$

Department of Chemistry, Capital Normal University, Beijing 100048, China. E-mail: jingzhou@cnu.edu.cn; Tel: +86-010-68902491

$\dagger$ Electronic supplementary information (ESI) available: Size distribution of $\mathrm{NaLuF}_{4}: \mathrm{Yb}$.Tm and UCNP; UCL spectra of $\mathrm{NaLuF}_{4}: \mathrm{Yb}$.Tm and UCNP; high-resolution TEM image and SAED patterns of UCNP; FTIR spectra of $\mathrm{NaLuF}_{4}: \mathrm{Yb}$.Tm and UCNP; UCL response of pretreated UCNP-PA-Ti solution with various concentrations of $\mathrm{F}^{-}$(medium concentration: $10 \mu \mathrm{M}$; high concentration: $20 \mu \mathrm{M}$ ) in various biological solutions; UCL response of pretreated UCNP-PA-Ti solution with $\mathrm{F}^{-}$in aqueous conditions containing various biomolecules; UCL response of UCNP-PA-Ti solution with various soluble fluorides; MTT assay and serum biochemistry tests; H\&E stained tissue sections; DLS of UCNP-PA-Ti within 30 days standing; UCL intensity of tubes presented in Fig. 3E and F. See DOI: 10.1039/c8sc00670a recent advance also demonstrated that transition metal ions and $\mathrm{F}^{-}$can form stable complexes via coordinate interaction and hence decrease the $\mathrm{F}^{-}$concentration. ${ }^{6}$ Moreover the complexes, possessing behavior like that of macromolecular drugs, can be excreted from the kidney through urine, which further shortens the $\mathrm{F}^{-}$excretion period. ${ }^{7}$ Apart from their therapeutic efficiency, traditional drugs lack the ability to quantify $\mathrm{F}^{-}$concentration for the purposes of diagnosis and monitoring of the therapeutic process. As a result of these shortcomings, a new type of drug is required for the integration of fluorosis therapy and diagnosis.

Nanomaterials have been explored as excellent vehicles for drug delivery. ${ }^{8-11}$ Therefore, nanomaterials modified with molecules containing transition metal ions have the potential to serve as nanodrugs for fluorosis therapy. Among all transition metal complexes, pyrogallic acid-titanium(rv) complex (PA-Ti) possesses high stability, high biocompatibility, and a low interaction with other biomolecules, which is promising for their bioapplication efficacy. Besides, the nanodrugs, equipped with the luminescence imaging function, also show great potential for the dynamic monitoring of $\mathrm{F}^{-}$concentration within a therapeutic process. ${ }^{12-14}$ Upconversion nanoprobes (UCNPs), excited by near-infrared (NIR) radiation, have been explored and studied as bioimaging nanophosphors for many years due to their high luminescence penetration, low autoluminescence from biosamples, high photostability, and adjustable multiple emission bands. ${ }^{15-19}$ These advantages promised UCNPs a bright future in not only bioimaging but molecule detection and biolabeling. ${ }^{20-24}$ Due to the surface quenching effect, an inner shell was required to minimize the 
energy loss and improve the luminescence efficiency. ${ }^{25}$ Therefore, the construction of core-shell UCNPs is much more favorable for bioapplications. Notably, if modified metal ioncontaining molecules are close enough to the UCNPs, which possess strong absorbance in the wavelength range of the upconversion luminescence (UCL) emission, a Förster resonance energy transfer (FRET) occurs between them and the UCL is quenched accordingly. ${ }^{26-28}$ By calculating the $\mathrm{d}-\mathrm{d}$ transition energy of PA-Ti and observing its absorbance spectrum, it was found that the absorbance overlapped with the blue emission of Tm-doped UCNPs, which allowed FRET generation. With $\mathrm{F}^{-}$ addition the modified PA-Ti decomposed, which led to the absorbance decreasing, FRET degeneration, and UCL recovery. Accordingly, a relationship can be established between the UCL intensity of PA-Ti-modified UCNPs and $\mathrm{F}^{-}$concentration. On account of the above facts, utilizing the strong coordinate interaction between titanium ions $\left(\mathrm{Ti}^{4+}\right)$ and $\mathrm{F}^{-}$, a novel UCNP-based nanoprobe with rational modification can be used for fluorosis therapy and $\mathrm{F}^{-}$concentration monitoring simultaneously.

In this work, a novel PA-Ti-modified $\mathrm{NaLuF}_{4}: \mathrm{Yb}, \mathrm{Tm}_{\mathrm{N}} @ \mathrm{NaLuF}_{4}$ (UCNP-PA-Ti) was developed for fluorosis theranostics. The $\mathrm{Ti}^{4+}$ can be complexed with $\mathrm{F}^{-}$, which results in PA-Ti decomposition, FRET weakening, and UCL recovery in the presence of $\mathrm{F}^{-}$ (Fig. 1A). The detection limit, linear range, and selectivity for $\mathrm{F}^{-}$ detection were studied in vitro, as well as their potential for fluorosis therapy. Further effort was made to illustrate the ex vivo fluorosis diagnosis capacity and the in vivo theranostics efficiency of UCNP-PA-Ti using mice as a model. This work, by simultaneously achieving fluorosis therapy and $\mathrm{F}^{-}$concentration monitoring, provides a new insight to the development of nanodrugs towards fluorosis theranostics.

\section{Experimental section}

\section{Preparation of pyrogallic acid-titanium(Iv) modified $\mathrm{NaLuF}_{4}: \mathrm{Yb}, \mathrm{Tm} @ \mathrm{NaLuF}_{4}$ (UCNP-PA-Ti)}

The $\mathrm{NaLuF}_{4}: \mathrm{Yb}, \mathrm{Tm} @ \mathrm{NaLuF}_{4}$ upconversion nanoparticles (UCNPs) were prepared via a typical solvothermal method. ${ }^{29,30}$ The bare UCNPs were obtained by removing oleic acid ligands on the surface via a reported ligand exchange method using nitrosonium tetrafluoroborate. ${ }^{\mathbf{3 1}}$ Further modification of the pyrogallic acid-titanium(Iv) complex was carried out in a bare
A

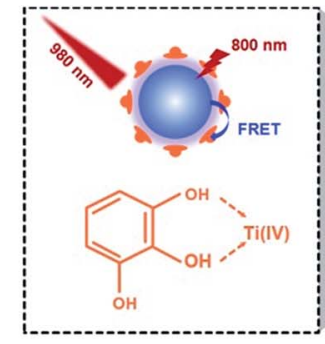

B
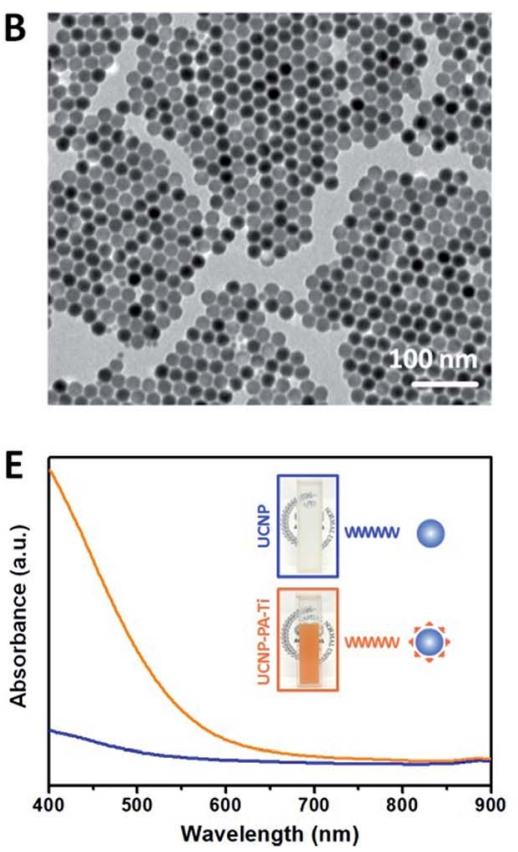

Natural light

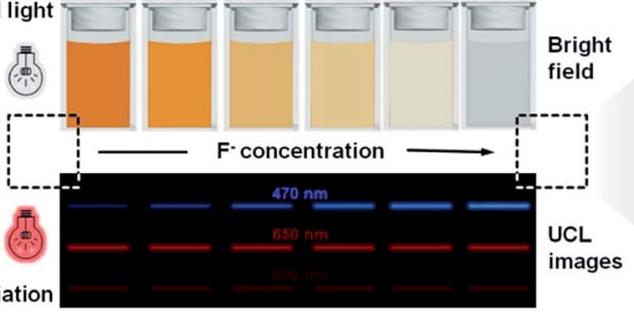

C
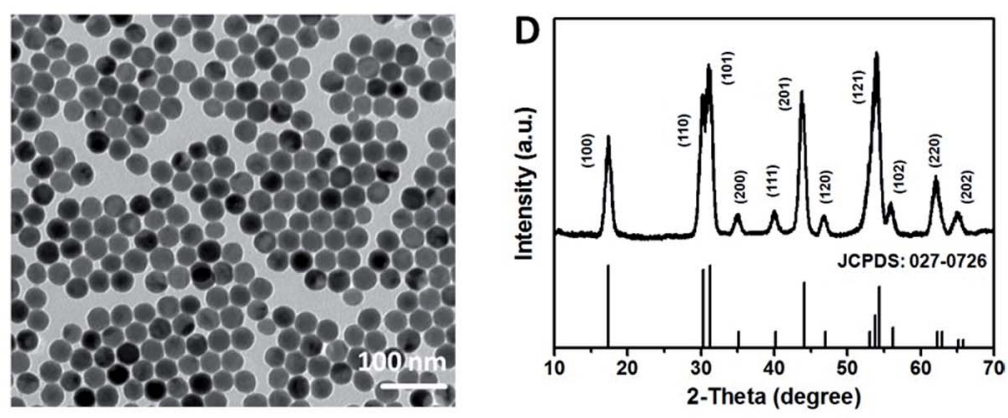

$\mathbf{F}$
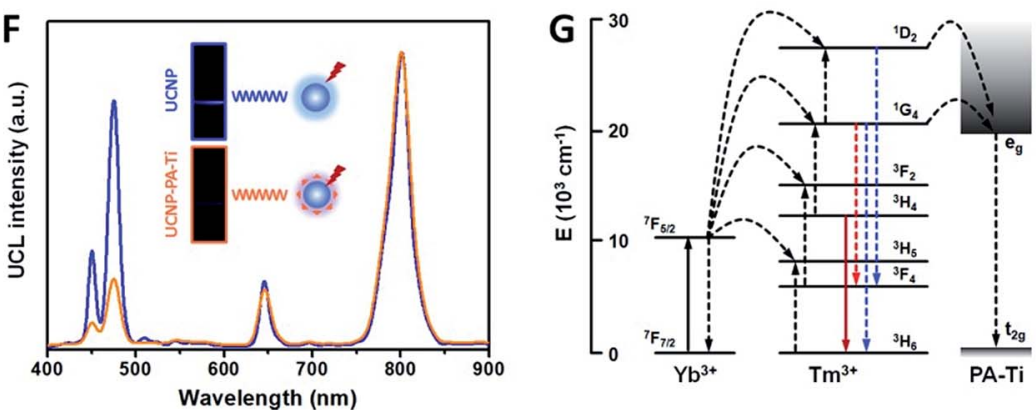

Fig. 1 Preparation and characteristics of the UCNP-PA-Ti nanoprobe. (A) Proposed mechanism for luminescence recovery of UCNP-PA-Ti in the presence of $\mathrm{F}^{-}$based on $\mathrm{PA}-\mathrm{Ti}$ decomposition and $\left[\mathrm{TiF}_{6}\right]^{2-}$ formation. TEM images of $\mathrm{NaLuF}_{4}: \mathrm{Yb}, \mathrm{Tm}(\mathrm{B})$ and NaLuF 4 :Yb,TmaNaLuF $\left(\mathrm{UCNP}_{4}\right)$ (C) prepared via a typical solvothermal method. (D) XRD pattern of UCNP. Absorbance spectra (E) and UCL spectra (F) of UCNP and UCNP-PA-Ti (inset: corresponding digital images under natural light and $980 \mathrm{~nm}$ irradiation). (G) Proposed mechanism of energy transfer between UCNPs and the modified PA-Ti complex. 
UCNP suspension to obtain UCNP-PA-Ti. Please see ESI $\dagger$ for experimental details.

\section{$\mathrm{F}^{-}$responsiveness and detection capacity study}

$\mathrm{NaF}$ was used as the source of $\mathrm{F}^{-} . \mathrm{F}^{-}$detection was performed under neutral conditions. In the $\mathrm{F}^{-}$detection experiment, $1 \mathrm{~mL}$ solutions of varying $\mathrm{F}^{-}$concentrations $(0-819.2 \mu \mathrm{M})$ were added into $1 \mathrm{~mL}$ of a UCNP-PA-Ti deionized (DI) water suspension $(20 \mu \mathrm{M})$ and incubated for $10 \mathrm{~min}$. To study the selectivity of UCNP-PA-Ti for $\mathrm{F}^{-}$detection, UCNP-PA-Ti was suspended in solutions containing various ions, amino acids, biomolecules, and proteins. Then, UV-vis-NIR and UCL spectra of all samples were measured.

\section{$\mathbf{F}^{-}$capture study}

The $\mathrm{F}^{-}$capture capacity of UCNP-PA-Ti was studied by mixing $1 \mathrm{~mL}$ solutions of varying $\mathrm{F}^{-}$concentrations $(0-819.2 \mu \mathrm{M})$ with $1 \mathrm{~mL}$ of a UCNP-PA-Ti DI water suspension $(20 \mu \mathrm{M})$. The mixtures were separated by centrifugation after $10 \mathrm{~min}$ of incubation. The precipitates were re-suspended in DI water and filtered for zeta potential measurement. In the $\mathrm{F}^{-}$capture study, 20 and $40 \mu \mathrm{mol} \mathrm{NaF}$ were each dissolved in samples of DI water, BSA solution, HSA solution, serum, and urine. Then, $1 \mathrm{~mL}$ of the above-mentioned solutions was added into $1 \mathrm{~mL}$ of a UCNP-PATi DI water suspension $(20 \mu \mathrm{M})$ and UCL spectra of all samples were measured after $10 \mathrm{~min}$ of incubation. The $\mathrm{F}^{-}$capture efficiency was determined by a fluorine ion selective electrode (Shanghai Leici PF-1).

\section{$\mathbf{F}^{-}$imaging and fluorosis therapy}

All animal procedures were performed in accordance with the Guidelines for Care and Use of Laboratory Animals of Beijing Vital River Laboratory Animal Technology Co., Ltd. and approved by the Animal Ethics Committee of the Vital River Institutional Animal Care and Use Committee (VR IACUC). Hepatocyte (CCC-HEL-1) cells were provided by the Institute of Basic Medical Sciences of the Chinese Academy of Medical Sciences. The cell UCL imaging experiment was performed using normal and $\mathrm{F}^{-}$pretreated CCC-HEL-1 cells. Healthy $\mathrm{BALB} / \mathrm{c}$ nude mice were used as a small-animal model for in vivo experimentation. Fluorosis models were established by providing mice with $50 \mathrm{mg} \mathrm{kg}{ }^{-1} \mathrm{NaF}$ solution. ${ }^{32}$ Please see ESI $\dagger$ for experimental details.

\section{Results and discussion}

\section{Preparation and characteristics of the UCNP-PA-Ti nanoprobe}

The core-shell $\mathrm{NaLuF}_{4}: \mathrm{Yb}, \mathrm{Tm} @ \mathrm{NaLuF}_{4}$ upconversion nanoparticles (UCNP) were developed via a typical solvothermal method. The transmission electron microscopy (TEM) images show that $\mathrm{NaLuF}_{4}: \mathrm{Yb}, \mathrm{Tm}$ has a uniform morphography with a narrow size distribution of $18.43 \pm 2.63 \mathrm{~nm}$ (Fig. 1B and $\mathrm{S} 1 \dagger$ ). After $\mathrm{NaLuF}_{4}$ shell coating, the size of the UCNPs increased to $24.72 \pm 2.77 \mathrm{~nm}$, which illustrated that the UCNPs with coreshell structure had been successfully prepared (Fig. 1C and S2 $\dagger$ ).
Importantly, the upconversion luminescence (UCL) intensity in both visible and near-infrared (NIR) regions improved after $\mathrm{NaLuF}_{4}$ shell coating, which can be attributed to the inhibition of multiphonon relaxation between the doping element $\left(\mathrm{Yb}^{3+}\right.$ and $\mathrm{Tm}^{3+}$ ) in the UCNPs and absorbed $\mathrm{H}_{2} \mathrm{O}$ molecules (Fig. S3 $\dagger$ ). ${ }^{33}$ Moreover, X-ray diffraction (XRD) patterns suggest that the UCNPs possess a highly crystalline hexagonal phase, corresponding to the standard card of $\beta-\mathrm{NaLuF}_{4}$ (JCPDS: 0270726, Fig. 1D). The high-resolution TEM (HR-TEM) image and selected area electron diffraction (SAED) patterns also confirmed this finding (Fig. S4†).

The pyrogallic acid-titanium(Iv) complex (PA-Ti) was then modified on the UCNPs using a ligand-exchange method (UCNP-PA-Ti). The successful modification can be identified from the ultraviolet-visible-near infrared (UV-vis-NIR) spectra and the Föurier transmission infrared (FTIR) spectra (Fig. 1E and $55 \dagger$ ). The UV-vis-NIR spectra show an intense absorbance band in the visible spectral region, which is attributed to $\mathrm{d}-\mathrm{d}$ band transitions between the lower energy $\left(t_{2 g}\right)$ and higher energy $\left(\mathrm{e}_{\mathrm{g}}\right)$ levels of $\mathrm{Ti}^{4+}$ (Fig. 1E and $\mathrm{G}$ ). Therefore, it was unsurprising to find that an energy transfer (ET) occurred between the UCNP and the modified PA-Ti, which caused the observable quenching of the blue emission from the UCNP, corresponding to the ${ }^{1} \mathrm{D}_{2} \rightarrow{ }^{3} \mathrm{~F}_{4}(452 \mathrm{~nm})$ and ${ }^{1} \mathrm{G}_{4} \rightarrow{ }^{3} \mathrm{H}_{6}$ $(470 \mathrm{~nm})$ transitions of $\mathrm{Tm}^{3+}$ (Fig. $1 \mathrm{~F}$ and $\mathrm{G}$ ). Moreover, the obtained UCNP-PA-Ti showed excellent solubility and stability in various biological fluids and $\mathrm{pH}$ conditions. They also possessed high photostability under laser irradiation (Table S1, Fig. S6 and $7 \dagger$ ). As a result of these findings, UCNP-PA-Ti was successfully prepared as a potential nanophosphor for further $\mathrm{F}^{-}$ capture and detection studies.

\section{Capture efficiency and UCL detection of $\mathrm{F}^{-}$by UCNP-PA-Ti}

As a novel nanoprobe for fluorosis theranostics, UCNP-PA-Ti is required to have a short $\mathrm{F}^{-}$capture period and a high capture efficiency in albumin-rich biological environments. Therefore, further efforts were made to improve the $\mathrm{F}^{-}$capture properties of UCNP-PA-Ti. In the presence of $\mathrm{F}^{-}$, the decomposition of modified PA-Ti complex can be observed both in the UV-vis-NIR spectra and with the naked eye due to the stronger interaction between $\mathrm{Ti}^{4+}$ and $\mathrm{F}^{-}$than the phenol groups in PA (Fig. 2A). The decreasing zeta potential results further confirm that $\mathrm{Ti}^{4^{+}}$is abscised from the nanoprobes and forms the complex $\left[\mathrm{TiF}_{6}\right]^{2-}$ (Fig. 2B). Besides, UCNP-PA-Ti can effectively capture $\mathrm{F}^{-}$in an albumin-rich environment, such as albumin solution and serum, no matter whether the $\mathrm{F}^{-}$concentration is high or low (Fig. S8 $\dagger$ ). To calculate the $\mathrm{F}^{-}$capture efficiency, an electrochemical method using an electrode that is selective for fluorine ions was used. According to the obtained results, $\mathrm{F}^{-}$solutions with the addition of UCNP-PA-Ti or PA-Ti had a significantly lower amount of free $\mathrm{F}^{-}$than other solutions, with a high $\mathrm{F}^{-}$ capture efficiency of $84.9 \pm 3.7 \%$ (Fig. 2C). With additional $\mathrm{F}^{-}$ added, the electronic signal recovered, which demonstrated that the $\left[\mathrm{TiF}_{6}\right]^{2-}$ complex does not influence the determination of free $\mathrm{F}^{-}$. More importantly the capture period, when the capture efficiency reached $80 \%$, was as low as 123.77 s after 

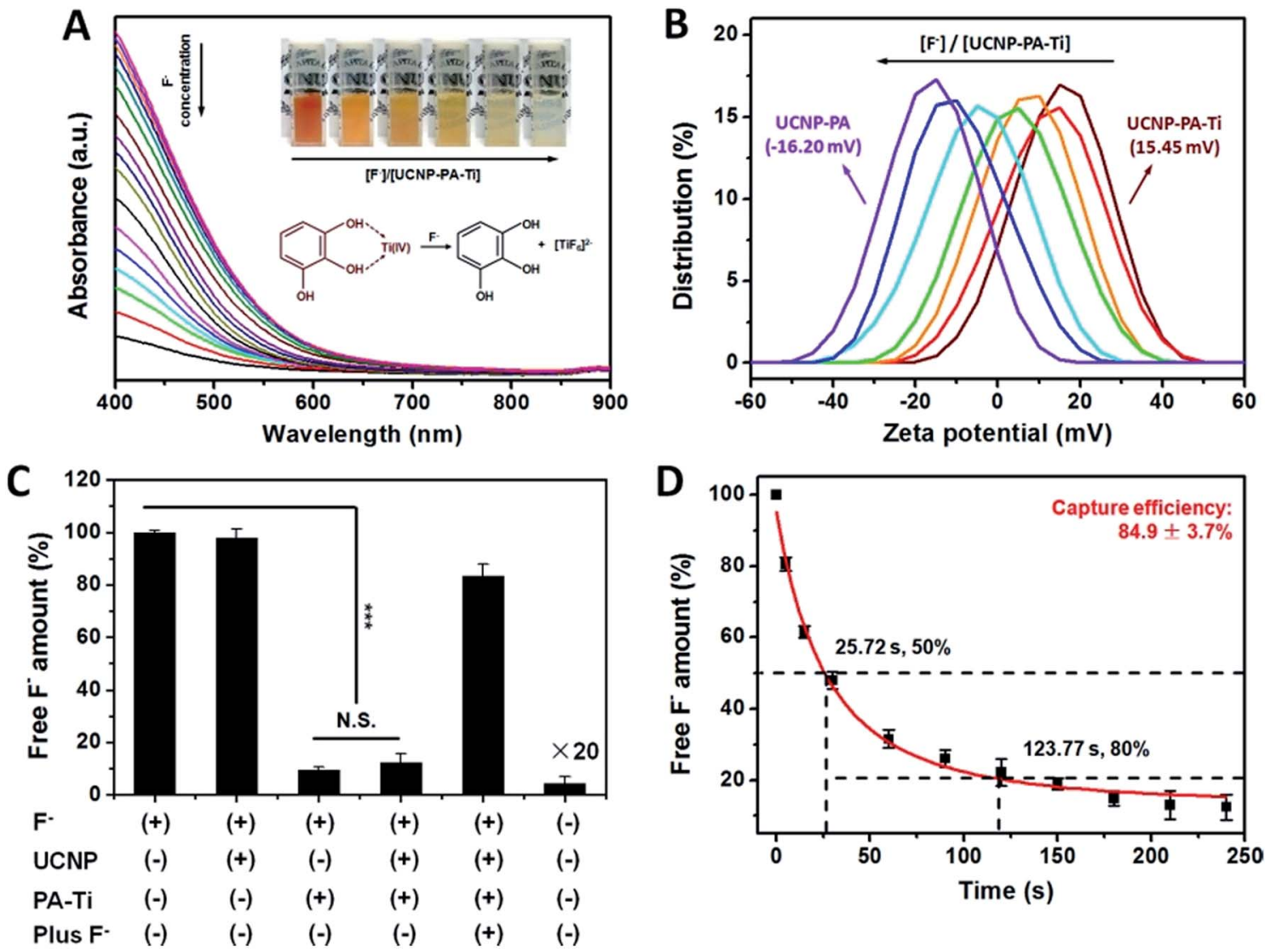

Fig. $2 \mathrm{~F}^{-}$capture and fluorosis therapeutic potential of UCNP-PA-Ti nanoprobes. (A) Absorbance of UCNP-PA-Ti in the presence of $\mathrm{F}^{-}$with various concentrations (inset: corresponding digital images under natural light). (B) Zeta potential of UCNP-PA and UCNP-PA-Ti treated with various concentrations of $\mathrm{F}^{-}$. (C) Free $\mathrm{F}^{-}$amount determined after $10 \mathrm{~min}$ with a fluorine selective electrode in a NaF solution with various treatments. (D) Residual $\mathrm{F}^{-}$amount over $4 \mathrm{~min}$ in a NaF solution treated with UCNP-PA-Ti.

UCNP-PA-Ti addition (Fig. 2D). The high $\mathrm{F}^{-}$capture efficiency and short capture period are advantageous for fluorosis therapy, as well as the rapid and sensitive detection of $\mathrm{F}^{-}$.

According to previous reports, ratiometric UCL detection strategies provide a straightforward means for facing the difficulties of single-band UCL detection by avoiding influences caused by concentration, absorption, scattering, and light sources. $^{34,35}$ To illustrate the capability of UCNP-PA-Ti for ratiometric $\mathrm{F}^{-}$UCL detection, the UCL spectra of UCNP-PA-Ti were measured after adding $\mathrm{F}^{-}$solutions of various concentrations. With increasing $\mathrm{F}^{-}$concentration, the luminescence of UCNP-PA-Ti in the $400-500 \mathrm{~nm}$ range recovered and the luminescence centered at $800 \mathrm{~nm}$ showed no obvious change with the addition of $\mathrm{F}^{-}$, which can be explained by the symmetric octahedral structure of formed $\left[\mathrm{TiF}_{6}\right]^{2-}$ and the inhibition of $\mathrm{d}-\mathrm{d}$ transitions (Fig. 3A). Besides, it can be found that the ratio of the intensities at $470 \mathrm{~nm}$ and $800 \mathrm{~nm}$, abbreviated as $I(470) / I(800)$, has a positive relationship with the $\mathrm{F}^{-}$ concentration of the added solution (Fig. 3B). It was noteworthy that in the concentration range of $50 \mathrm{nM}$ to $26 \mu \mathrm{M}, I(470) / I(800)$ was positively linearly correlated with $\mathrm{F}^{-}$concentration $(I(470) /$ $I(800)=0.05713+0.02131 \mathrm{~F}^{-} / \mu \mathrm{M}, R^{2}=0.99874$, and LOD: 4.2 $\mathrm{nM}$ ). Meanwhile, the UCL emission at $650 \mathrm{~nm}$ can also be used as a reference for ratiometric detection since the UCL intensity centered at $650 \mathrm{~nm}$ barely changed after $\mathrm{F}^{-}$addition (Fig. 3C). $I(470) / I(650)$ increased linearly as the $\mathrm{F}^{-}$concentration increased in the range of $50 \mathrm{nM}$ to $26 \mu \mathrm{M}(I(470) / I(650)=$ $1.10047+0.04553 \mathrm{~F}^{-} / \mu \mathrm{M}, R^{2}=0.99605$, and LOD: $\left.4.2 \mathrm{nM}\right)$. Based on the above findings, the $\mathrm{F}^{-}$concentration can be determined via the measurement of UCL intensity and calculation of $I(470) / I(800)$ or $I(470) / I(650)$. Compared to recently reported nanoprobes, UCNP-PA-Ti has favorable $\mathrm{F}^{-}$detection capabilities (Table S3†). Moreover, the recovery of the blue emission $(470 \mathrm{~nm})$ of UCNP-PA-Ti can also be observed by the naked eye, which is favorable for the development of a potential paper-based device for $\mathrm{F}^{-}$detection (Fig. 3D).

The feasibility of UCNP-PA-Ti for ratiometric UCL imaging of $\mathrm{F}^{-}$was also studied to explore its potential for further application. The UCL signals were collected at $400-600 \mathrm{~nm}$, $600-700 \mathrm{~nm}$, and $800 \pm 12 \mathrm{~nm}$ by a charge-coupled device (Fig. 3E and F). With increasing concentration of $\mathrm{F}^{-}$, the UCL signal intensity in the range of 400-600 nm increased accordingly. Meanwhile, 600-700 nm and $800 \pm 12 \mathrm{~nm}$ UCL signal intensities showed no observable change (Table S4 †). Besides, UCNP-PA-Ti had no response to typical ions, amino acids, biomolecules, and proteins from living systems (Fig. 3G-I, S9 and S10†). Importantly, other anions showed a negative influence on $\mathrm{F}^{-}$detection of UCNP-PA-Ti (Fig. S11 $\dagger$ ). Besides, 


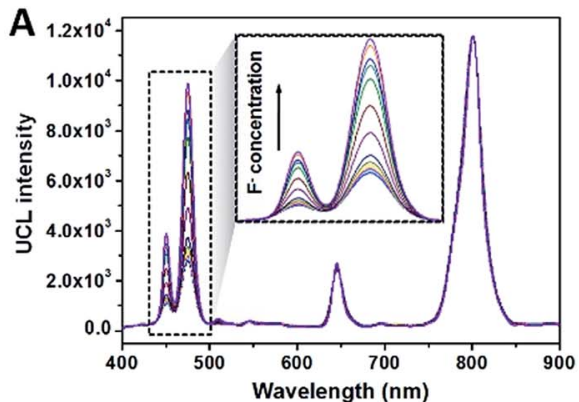

D
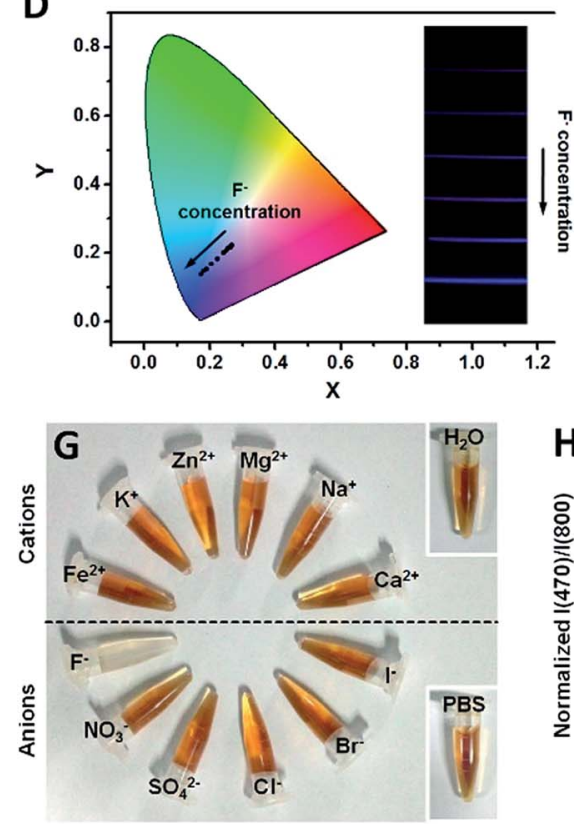

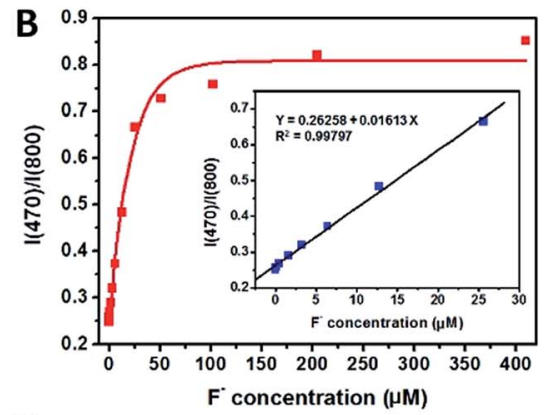

$E$
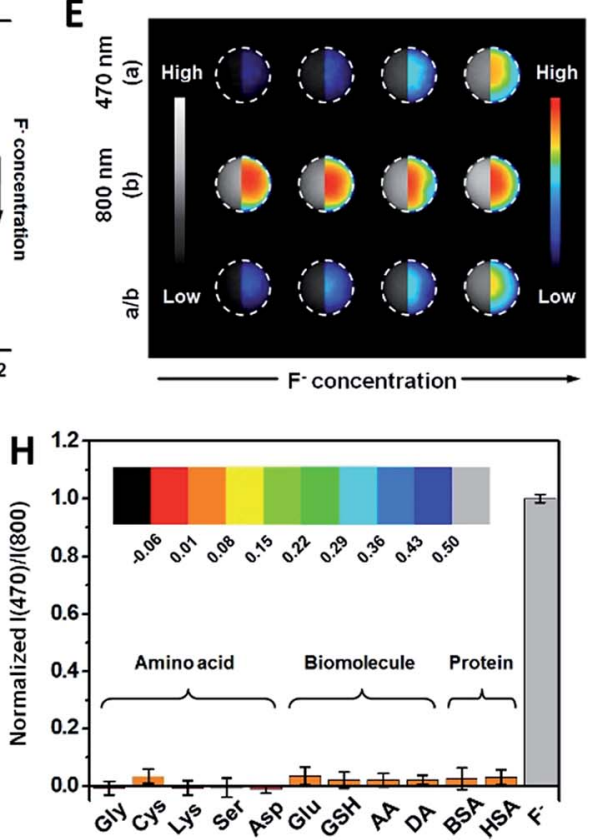

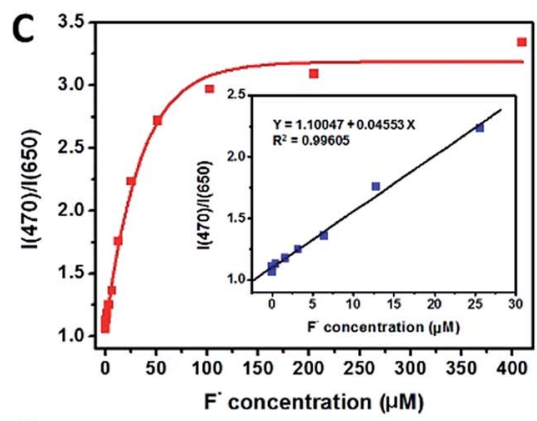

$\mathbf{F}$

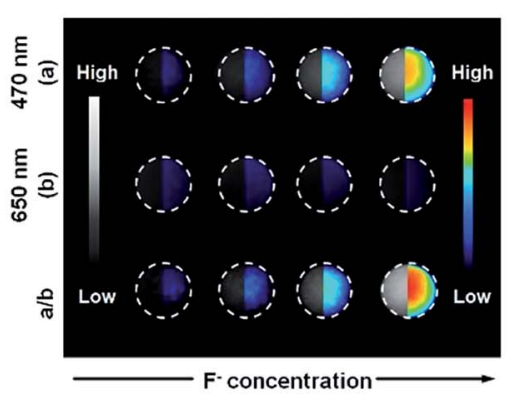

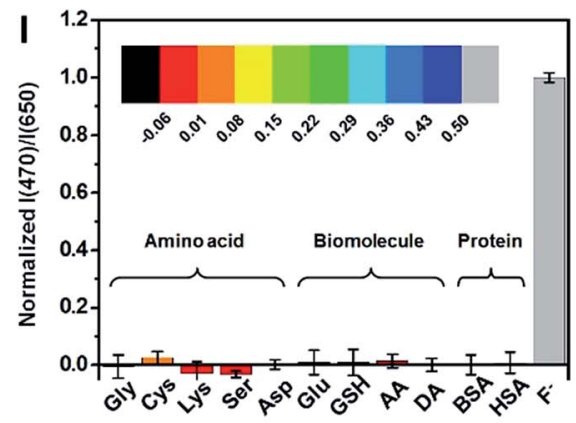

Fig. $3 \mathrm{~F}^{-}$detection capacities of the UCNP-PA-Ti nanoprobe. (A) UCL spectra of UCNP-PA-Ti reacted with different concentrations of $\mathrm{F}^{-}$. The linear relationship between $\mathrm{F}^{-}$concentrations and $/(470) / /(800)(\mathrm{B})$ and $/(470) / /(650)$ (C) in the range from $50 \mathrm{nM}$ to $26 \mu M$. (D) Corresponding Commission Internationale de l'Eclairage (CIE) chromaticity coordinates and corresponding UCL digital images (inset). UCL signal collected using a small animal UCL imaging system at $470 \mathrm{~nm} / 800 \mathrm{~nm}(E)$, and $470 \mathrm{~nm} / 650 \mathrm{~nm}$ (F). (G) Digital images of UCNP-PA-Ti solution mixed with various ions. Normalized $/(470) / /(800)(\mathrm{H})$ and $/(470) / /(650)(\mathrm{I})$ of UCNP-PA-Ti solution mixed with various amino acid, biomolecules, and proteins.

soluble fluoride species exhibited no influence on the quantification of $\mathrm{F}^{-}$(Fig. S12†). Due to the penetration difference between $650 \mathrm{~nm}$ and $800 \mathrm{~nm}$ UCL in bioimaging, it is rational to use $650 \mathrm{~nm}$ in cell imaging and $800 \mathrm{~nm}$ in small animal imaging as references. As a result of these advantages, UCNP-PA-Ti is a promising nanoprobe for use in the ratiometric UCL imaging of $\mathrm{F}^{-}$both in vitro and in vivo.

\section{Fluorosis theranostics and $\mathrm{F}^{-}$concentration monitoring}

Fluorosis, caused by continuous high $\mathrm{F}^{-}$uptake, can induce a great many chronic diseases such as skeletal deformity, arthralgia, and liver fibrosis. ${ }^{36}$ Therefore, the use of fluorosis theranostics in the early stages of disease is essential. With $\mathrm{F}^{-}$ responsive UCL emissions, high $\mathrm{F}^{-}$capture efficiency, and the ability to produce a soluble metabolite with a small hydrodiameter, UCNP-PA-Ti has great potential in both fluorosis diagnosis and rapid renal $\mathrm{F}^{-}$excretion (Fig. S13 and $14 \dagger$ ). To demonstrate their fluorosis theranostic properties, ratiometric
UCL imaging of $\mathrm{F}^{-}$was performed. Live hepatocyte (CCC-HEL-1 cell line) was used as a cell model for UCL cell imaging. After incubation with UCNP-PA-Ti, strong UCL can be observed in the cytoplasm of live hepatocyte, demonstrating that the nanoprobe can be rapidly uptaken by cells and accumulate in $\mathrm{F}^{-}$-containing electrolytes, which is favorable for $\mathrm{F}^{-}$detection (Fig. 4A). Importantly, with the increase in pretreated $\mathrm{F}^{-}$ concentration, UCL intensity in live hepatocyte collected in the blue channel (400-600 $\mathrm{nm}$, abbreviated as B) is enhanced, while the red channel $(650 \pm 15 \mathrm{~nm}$, abbreviated as R) showed no obvious change. The blue and red UCL emission intensities obtained from cells were then quantified and the $\mathrm{B} / \mathrm{R}$ ratio was calculated as a function of increasing $\mathrm{F}^{-}$concentration (Fig. 4B). It was found that the $\mathrm{B} / \mathrm{R}$ ratio is positively correlated with $\mathrm{F}^{-}$concentration, increasing from 1.029 to 3.315 , which can be verified as being significant. This result illustrated not only the highly efficient reaction between the nanoprobes and $\mathrm{F}^{-}$in cells, but the feasibility of UCNP-PA-Ti for $\mathrm{F}^{-}$detection via ratiometric UCL imaging in cells. 
A
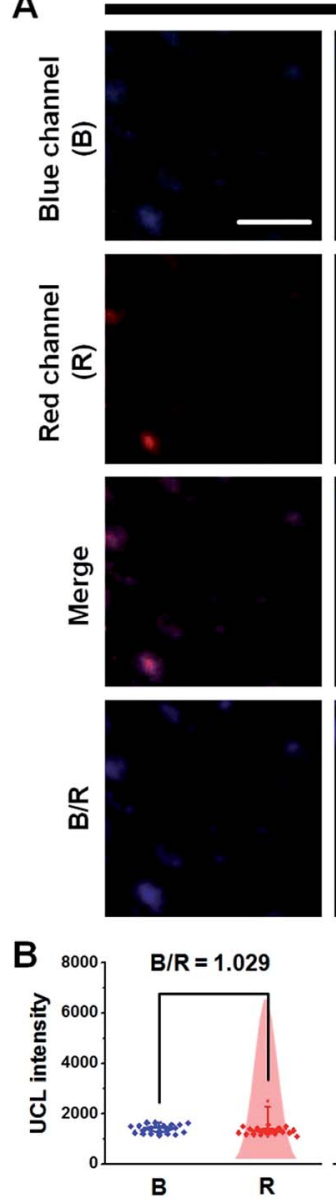
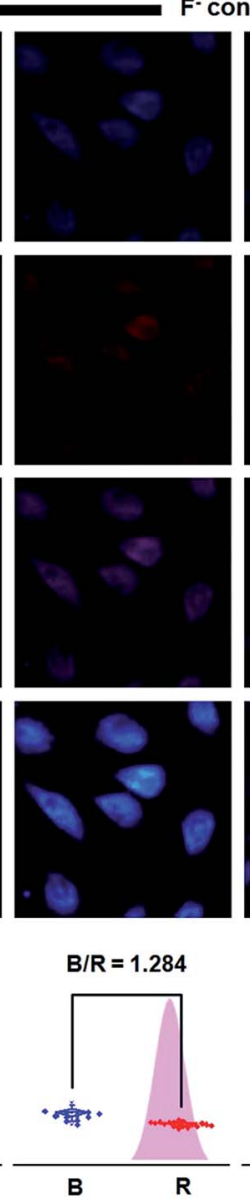
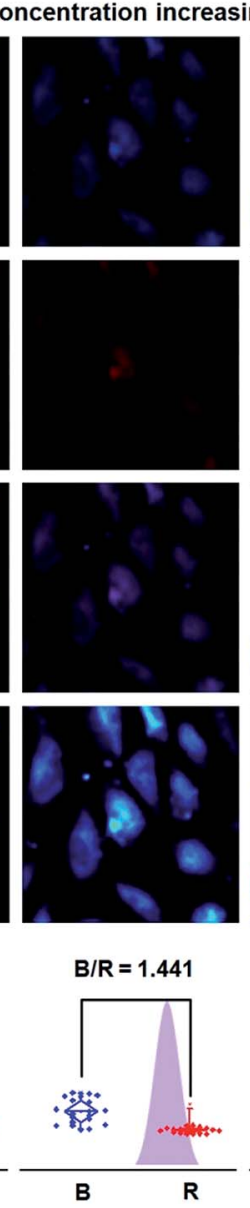
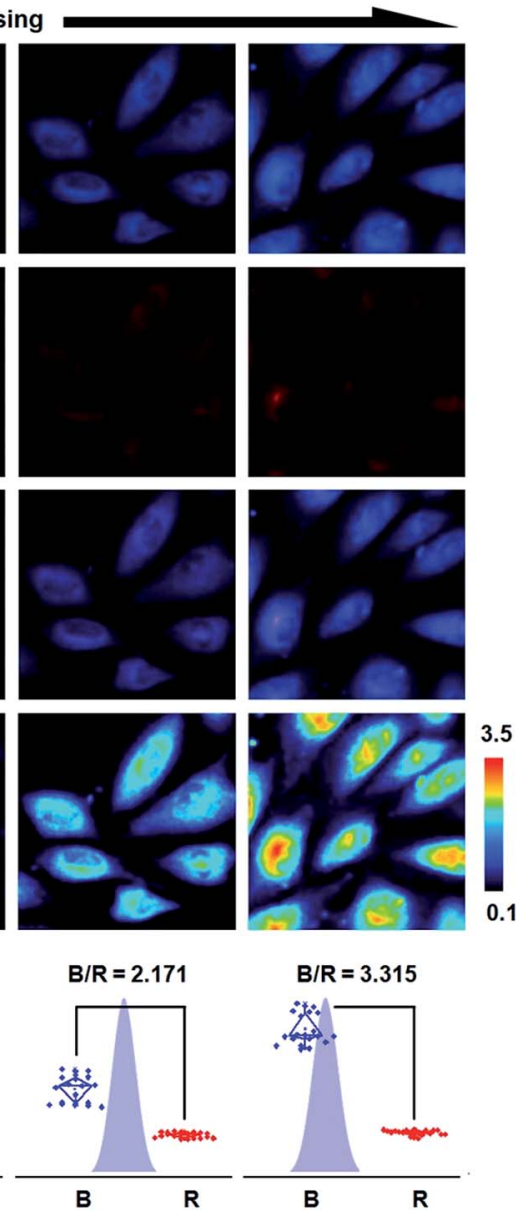

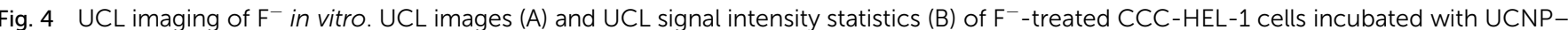

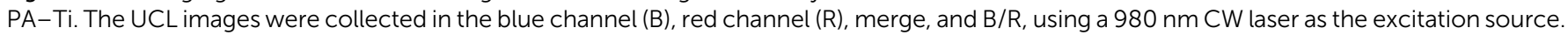
The scale bar is $50 \mu \mathrm{m}$.

Further efforts were made on in vivo ratiometric UCL imaging using mice suffering from fluorosis as a model. A strong UCL signal can be observed in mice that have received an intravenous injection of UCNP-PA-Ti (Fig. 5A and B). It is noteworthy that the blue UCL signal collected in the range 400$600 \mathrm{~nm}$ from normal mice was obviously lower than that from mice suffering from fluorosis, while the NIR UCL signal at $800 \pm$ $12 \mathrm{~nm}$ (abbreviated as $\mathrm{N}$ ) showed no significant difference. The $\mathrm{B} / \mathrm{N}$ ratio was calculated to illustrate the feasibility for $\mathrm{F}^{-}$ monitoring in vivo. Obviously, a higher $\mathrm{B} / \mathrm{N}$ ratio was found for mice suffering from fluorosis than for normal mice, which suggested that UCNP-PA-Ti can react with $\mathrm{F}^{-}$in vivo, resulting in the recovery of blue UCL emission. The UCL images of dissected organs suggested that UCNP-PA-Ti had high retention in the reticuloendothelial system of mice, such as the liver and spleen (Fig. 5C and D), which corresponds to the biodistribution of UCNP-PA-Ti (inset in Fig. 5E). It was also found that UCNP-PA-Ti accumulated in the kidney, which might be a result of their prolonged blood circulation time and relatively low hydrodiameter (Fig. 5E). Corresponding to the UCL images in vivo and biodistribution of UCNP-PA-Ti, the blue UCL emission intensity in dissected organs obtained from mice suffering from fluorosis was significantly high, while that from normal mice was low (Fig. 5F). To quantify the $\mathrm{F}^{-}$ratiometric imaging feasibility, the $\mathrm{B} / \mathrm{N}$ ratio in organs was calculated. It was found that the $\mathrm{B} / \mathrm{N}$ ratio for the organs of mice suffering from fluorosis $(0.781 \pm 0.088)$ was significantly higher than that of the organs of normal mice $(0.311 \pm 0.073)$, which was in good agreement with the ratiometric UCL imaging in vivo (Fig. 5G). The above results strongly demonstrate the feasibility of UCNP$\mathrm{PA}-\mathrm{Ti}$ for $\mathrm{F}^{-}$detection and ratiometric imaging in vivo. Therefore, UCL imaging was used to monitor standard $\mathrm{F}^{-}$concentration within the therapeutic process.

Since UCNP-PA-Ti can effectively react with $\mathrm{F}^{-}$and showed a sensitive UCL responsive in vivo, the UCL imaging-monitored therapeutic efficiency was then studied using mice suffering from fluorosis as a model. Within the fluorosis therapeutic process, mice suffering from fluorosis received an intravenous injection of UCNP-PA-Ti. UCL images were taken and humoral samples were collected at various time points (Fig. 6A). After intravenous injection, UCNP-PA-Ti circulated in the vessels and captured $\mathrm{F}^{-}$in the blood, forming stable complexes and decreasing free $\mathrm{F}^{-}$concentration, and accelerating metabolism. As shown in Fig. 6B, blue UCL emission intensity decreased 

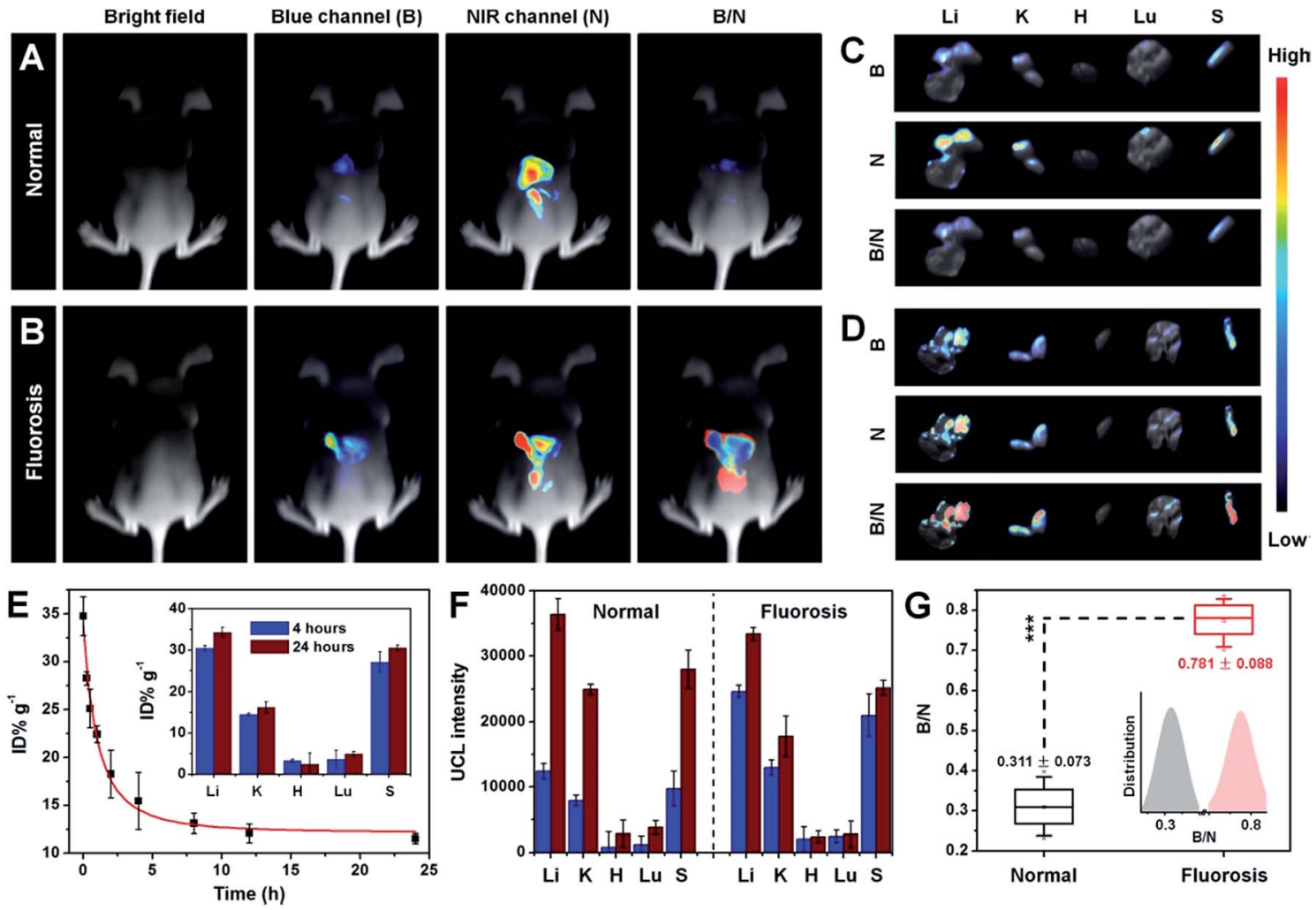

Fig. $5 \mathrm{UCL}$ imaging of $\mathrm{F}^{-}$in vivo and ex vivo. The UCL images obtained from bright field, blue channel (B), NIR channel (N), and their ratio (B/N) of normal mice (A) and mice suffering from fluorosis (B) following intravenous injection of UCNP-PA-Ti . Representative UCL images of dissected organs of normal mice (C) and mice suffering from fluorosis (D) sacrificed 60 min after intravenous injection with UCNP-PA-Ti. (E) Blood circulation curve of UCNP-PA-Ti after intravenous injection at different time points post-injection (inset: accumulation amount of UCNP-PA-Ti in various organs at 4 and $24 \mathrm{~h}$ post-injection). The unit is percentage of injected dose per gram of tissue $\left(\% \mathrm{ID} \mathrm{g}{ }^{-1}\right)$. Quantitative analysis of $U C L$ intensity (blue bar: $\mathrm{B}$; red bar: N) (F) and B/N (G) obtained from UCL images of dissected organs.

accordingly while the NIR UCL emission showed no observable change. More importantly, not only the blue emission intensity but the $\mathrm{B} / \mathrm{N}$ ratio decreased from 0.57 to 0.28 throughout the therapeutic process (Fig. 6C-E). The time-dependent decrease of blue UCL emission intensity, as well as $\mathrm{B} / \mathrm{N}$, can be explained by the blood $\mathrm{F}^{-}$concentration gradually decreasing after receiving the UCNP-PA-Ti injection. With a low $\mathrm{F}^{-}$concentration in the blood, only a few PA-Ti complexes would be decomposed by $\mathrm{F}^{-}$, which resulted in low blue UCL recovery in UCNP-PA-Ti accumulated organs. To further demonstrate the therapeutic efficiency of UCNP-PA-Ti as nanodrugs for fluorosis therapy, three typical indexes were determined, namely, the $\mathrm{F}^{-}$ concentration in blood and urine, as well as the $\mathrm{F}^{-}$amount in feces. Within a 7 day therapeutic period, the $\mathrm{F}^{-}$concentration in blood continuously decreased and essentially returned to normal (Fig. 6F), compared to normal mice. However, the blood $\mathrm{F}^{-}$concentration in those mice receiving no therapy remained high, a significant difference to those receiving therapy. The $\mathrm{F}^{-}$ amount in feces and $\mathrm{F}^{-}$concentration in urine, generated from mice suffering from fluorosis that received therapy, were higher than in those receiving no therapy for the first few days and then decreased rapidly in the last period (Fig. 6G and H). Moreover, the outstanding stability of the $\left[\mathrm{TiF}_{6}\right]^{2-}$ complex in urine ensured the safety of its renal metabolic pathway. These phenomena can be explained due to the highly efficient fluoride expulsion and accelerated fluorine metabolism through the liver and kidney. These results provide solid evidence for the high fluorosis therapeutic efficiency of UCNP-PA-Ti in living systems with rapid and efficient metabolism.

\section{Cytotoxicity and biocompatibility in vivo}

Though the safety of rare-earth upconversion nanoprobes for bioapplications has been demonstrated previously, a detailed toxicity study of the designed UCNP-PA-Ti was still required. ${ }^{37,38}$ The 3-(4,5-dimethylthiazol-2-yl)-2,5-diphenyltetrazolium bromide (MTT) assay was used to evaluate their cytotoxicity. CCC-HEL-1 cells remained of high cellular viability $(>90 \%)$ within incubation processes of 24 and $48 \mathrm{~h}$ with various concentrations of UCNP-PA-Ti, which demonstrated the lack of significant cytotoxicity of UCNP-PA-Ti to normal cells (Fig. S15A †े). Further efforts were undertaken, focusing on biocompatibility in vivo. Healthy mice were given an intravenous injection of UCNP-PA-Ti $\left(20 \mathrm{mg} \mathrm{kg}^{-1}\right.$ ) and monitored for 30 days. The mice receiving the UCNP-PA-Ti injection neither died nor showed observable abnormal behavior. Moreover, complete blood panel tests and serum biochemistry assays were performed, which mainly focused on liver and kidney functions, testing indicators including alanine aminotransferase (ALT), aspartate aminotransferase (AST), total bilirubin (TBIL), total protein (TP), 
A

\section{A}
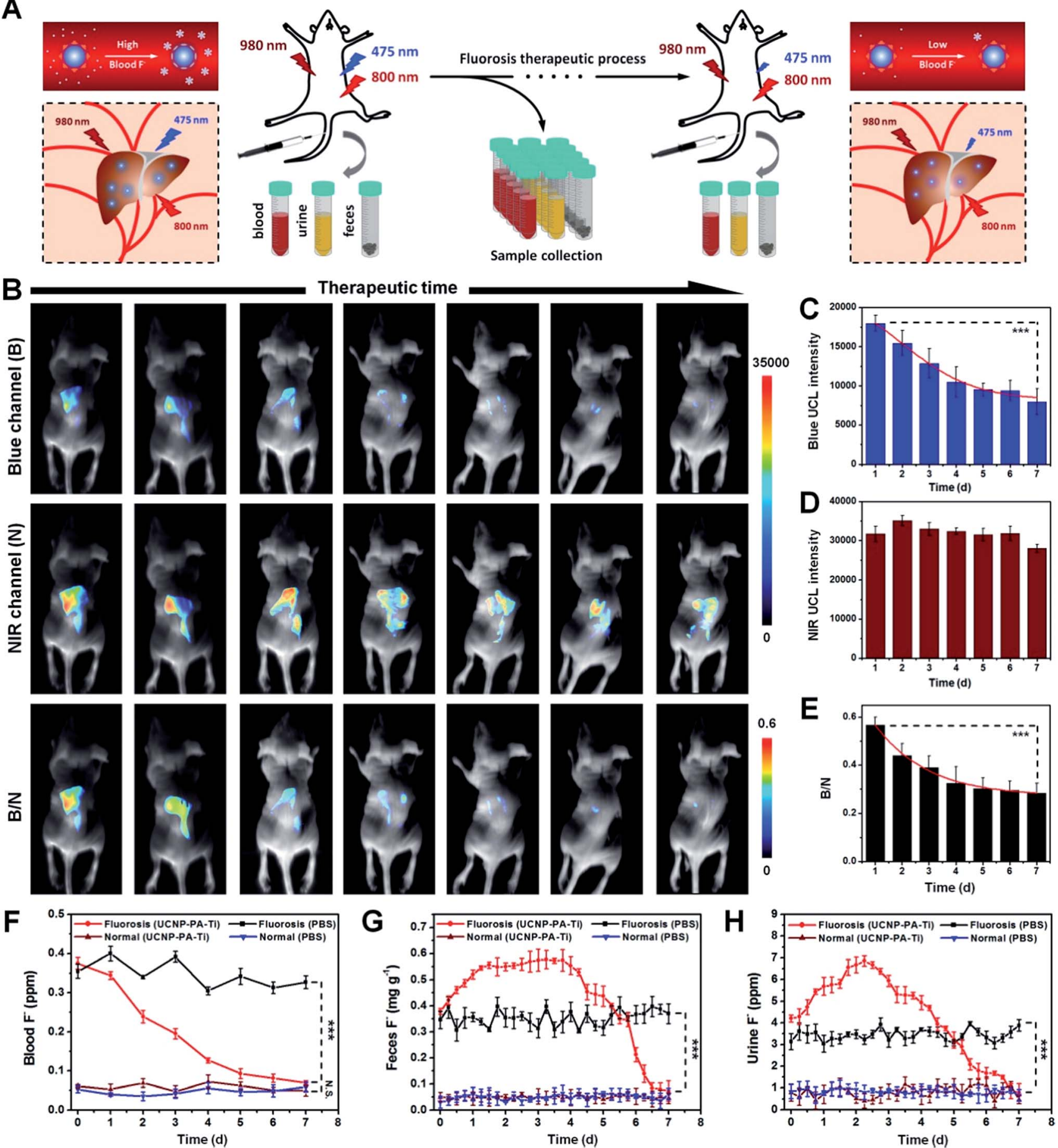

Fig. 6 UCL imaging-guided fluorosis therapy in vivo. (A) Mechanism scheme of UCL imaging-monitored fluorosis therapy. (B) UCL images of mice suffering from fluorosis obtained from the blue channel (B), NIR channel (N), and B/N ratio throughout the therapeutic process. Blue UCL signal intensity $(C), N I R$ UCL signal intensity $(D)$, and $B / N$ ratio $(E)$ calculated from $(B) . F^{-}$amount in blood $(F)$, feces $(G)$, and urine $(H)$ of mice suffering from fluorosis throughout the therapeutic process.

albumin (ALB), and creatinine (CREA) (Fig. S15B-D†). The results illustrated that no significant content differences can be found between mice receiving PBS (Blank) or a UCNP-PA-Ti injection within 30 days, suggesting that UCNP-PA-Ti wouldn't induce palpable liver or kidney function disturbances. In addition, hematoxylin-eosin (H\&E) stained histological examinations of primary organs - these being the heart, liver, spleen, lung, and kidney - suggested that UCNP-PA-Ti wouldn't induce organ morphology abnormity and pathological changes (Fig. S16†). As a result of the above systematic investigation, the safety of UCNPPA-Ti for fluorosis theranostics at our tested dosage range has been solidly confirmed. 


\section{Conclusion}

In this work, a novel PA-Ti-modified upconversion nanoprobe was rationally designed for $\mathrm{F}^{-}$detection and fluorosis theranostics. Since $\mathrm{Ti}^{4+}$ can capture $\mathrm{F}^{-}$by a strong complex interaction, PA-Ti decomposed and colorless $\left[\mathrm{TiF}_{6}\right]^{2-}$ formed simultaneously after $\mathrm{F}^{-}$addition, resulting in FRET weakening and UCL recovery. Due to the high $\mathrm{F}^{-}$capture efficiency of UCNP-PA-Ti $(84.9 \pm 3.7 \%)$, the nanoprobe showed high sensitivity and a selective response to $\mathrm{F}^{-}$. The low detection limit (4.2 $\mathrm{nM})$ and broad linear range (50 nM to $26 \mu \mathrm{M})$ promised outstanding performance in $\mathrm{F}^{-}$detection and UCL imaging both in vitro and in vivo. As a result of the above facts, ratiometric UCL imaging-monitored fluorosis therapy was successfully performed on mice suffering from fluorosis as a model, and the nanoprobe was found to reduce the blood and urine $\mathrm{F}^{-}$ concentration within the treatment period. Moreover, the nanoprobe also showed excellent stability and low toxicity, which ensured its safe use in bioapplications. This work provides new insight for the development of next generation nanodrugs towards imaging-monitored fluorosis therapy.

\section{Author contributions}

Y. L. and J. Z. conceived the project, analyzed the results, and wrote the manuscript. Q. J. and X. Z. synthesized the UCNP-PATi. Y. L., A. J., and L. L. conducted the characterisation of UCNPPA-Ti. Y. L. and L. M. performed the in vitro and in vivo UCL imaging. Y. L. conducted other experiments.

\section{Conflicts of interest}

There are no conflicts to declare.

\section{Acknowledgements}

The authors are thankful for funding from the National Natural Science Foundation of China (21301121), the Beijing talent foundation outstanding young individual project (2015000026833ZK02), the project of High-level Teachers in Beijing Municipal Universities in the Period of 13th Five-year Plan (IDHT20180517), the project of Construction of Scientific Research Base by the Beijing Municipal Education Commission, the Yanjing Young Scholar Development Program of Capital Normal University, and the Youth Innovative Research Team of Capital Normal University. Capacity Building for Sci-Tech Innovation-Fundamental Scientific Research Funds (025185305000/195).

\section{References}

1 G. Iolascon, R. Gimigliano, M. Bianco, A. de Sire, A. Moretti, A. Giusti, N. Malavolta, S. Migliaccio, A. Migliore, N. Napoli, P. Piscitelli, G. Resmini, U. Tarantino and F. Gimigliano, J. Nutr., Health Aging, 2017, 21, 527-538.

2 P. Grandjean and P. J. Landrigan, Lancet Neurol., 2014, 13, 330-338.
3 P. Shah, S. A. Rahman, H. Demirbilek, M. Güemes and

K. Hussain, Lancet Diabetes Endocrinol., 2017, 5, 729-742.

4 D. Taves, Nature, 1968, 217, 1050-1051.

5 D. Myers and T. Lyon, Pediatr. Dent., 1986, 8, 213-215.

6 M. P. Whyte, K. Essmyer, F. H. Gannon and W. R. Reinus, Am. J. Med., 2005, 118, 78-82.

7 M. Torra, M. Rodamilans and J. Corbella, Biol. Trace Elem. Res., 1998, 63, 67-71.

8 L. Wang, C. Gao, K. Liu, Y. Liu, L. Ma, L. Liu, X. Du and J. Zhou, Adv. Funct. Mater., 2016, 26, 3480-3489.

9 Y. Dai, C. Xu, X. Sun and X. Chen, Chem. Soc. Rev., 2017, 46, 3830-3852.

10 M. Huo, L. Wang, Y. Chen and J. Shi, Nat. Commun., 2017, 8, 357.

11 G. Yang, L. Xu, Y. Chao, J. Xu, X. Sun, Y. Wu, R. Peng and Z. Liu, Nat. Commun., 2017, 8, 902.

12 O. Wolfbeis, Chem. Soc. Rev., 2015, 44, 4743-4768.

13 X. M. Liu, Q. Zhao, W. C. Song and X. H. Bu, Chem.-Eur. J., 2012, 18, 2806-2811.

14 Y. P. Li, Q. Zhao, H. R. Yang, S. J. Liu, X. M. Liu, Y. H. Zhang, T. L. Hu, J. T. Chen, Z. Chang and X. H. Bu, Analyst, 2013, 138, 5486-5494.

15 R. Deng, F. Qin, R. Chen, W. Huang, M. Hong and X. Liu, Nat. Nanotechnol., 2015, 10, 237-242.

16 X. Li, Z. Guo, T. Zhao, Y. Lu, L. Zhou, D. Zhao and F. Zhang, Angew. Chem., Int. Ed., 2016, 128, 2510-2515.

17 J. Lee, B. Yoo, H. Lee, G. D. Cha, H.-S. Lee, Y. Cho, S. Y. Kim, H. Seo, W. Lee, D. Son, M. Kang, H. M. Kim, Y. I. Park, T. Hyeon and D.-H. Kim, Adv. Mater., 2017, 29, 1603169.

18 P. Lei, R. An, S. Yao, Q. Wang, L. Dong, X. Xu, K. Du, J. Feng and H. Zhang, Adv. Mater., 2017, 29, 1700505.

19 X. Zhu, Q. Su, W. Feng and F. Li, Chem. Soc. Rev., 2017, 46, 1025-1039.

20 Y. Liu, S. Zhou, Z. Zhuo, R. Li, Z. Chen, M. Hong and X. Chen, Chem. Sci., 2016, 7, 5013-5019.

21 X. Zhu, W. Feng, J. Chang, Y.-W. Tan, J. Li, M. Chen, Y. Sun and F. Li, Nat. Commun., 2016, 7, 10437.

22 J. Xu, S. Zhou, D. Tu, W. Zheng, P. Huang, R. Li, Z. Chen, M. Huang and X. Chen, Chem. Sci., 2016, 7, 2572-2578.

23 H. Dong, L.-D. Sun, W. Feng, Y. Gu, F. Li and C.-H. Yan, ACS Nano, 2017, 11, 3289-3297.

24 J. Peng, A. Samanta, X. Zeng, S. Han, L. Wang, D. Su, D. T. B. Loong, N.-Y. Kang, S.-J. Park, A. H. All, W. Jiang, L. Yuan, X. Liu and Y.-T. Chang, Angew. Chem., Int. Ed., 2017, 56, 4165-4169.

25 L. Ma, Y. Liu, L. Liu, A. Jiang, F. Mao, D. Liu, L. Wang and J. Zhou, Adv. Funct. Mater., 2017, 28, 1705057.

26 Y. Liu, Q. Jia, Q. Guo, A. Jiang and J. Zhou, Anal. Chem., 2017, 89, 12299-12305.

27 Q. Su, W. Feng, D. Yang and F. Li, Acc. Chem. Res., 2017, 50, 32-40.

28 Q. Guo, Y. Liu, Q. Jia, G. Zhang, H. Fan, L. Liu and J. Zhou, Anal. Chem., 2017, 89, 4986-4993.

29 R. A. Jalil and Y. Zhang, Biomaterials, 2008, 29, 4122-4128.

30 Y. Liu, Q. Guo, X. Zhu, W. Feng, L. Wang, L. Ma, G. Zhang, J. Zhou and F. Li, Adv. Funct. Mater., 2016, 26, 5120-5130. 
31 A. G. Dong, X. C. Ye, J. Chen, Y. J. Kang, T. Gordon, J. M. Kikkawa and C. B. Murray, J. Am. Chem. Soc., 2010, 133, 998-1006.

32 L. Zhao, Y. Yu and C. Deng, Toxicol. Lett., 2014, 225, 318-324.

33 R. Arppe, I. Hyppanen, N. Perala, R. Peltomaa, M. Kaiser, C. Wurth, S. Christ, U. Resch-Genger, M. Schaferling and T. Soukka, Nanoscale, 2015, 7, 11746-11757.

34 P. Wang, C. Zhang, H.-W. Liu, M. Xiong, S.-Y. Yin, Y. Yang, X.-X. Hu, X. Yin, X.-B. Zhang and W. Tan, Chem. Sci., 2017, 8, 8214-8220.
35 X. Hu, Y. Wang, H. Liu, J. Wang, Y. Tan, F. Wang, Q. Yuan and W. Tan, Chem. Sci., 2017, 8, 466-472.

36 N. I. Agalakova and G. P. Gusev, J. Evol. Biochem. Physiol., 2011, 47, 393-406.

37 A. Gnach, T. Lipinski, A. Bednarkiewicz, J. Rybka and J. A. Capobianco, Chem. Soc. Rev., 2015, 44, 1561-1584.

38 J. Zhou, Q. Liu, W. Feng, Y. Sun and F. Li, Chem. Rev., 2015, 115, 395-465. 